\title{
The Economies of the BELL Countries (Bulgaria, Estonia, Latvia and Lithuania) after Their EU Accession
}

\author{
Emilia Georgieva ${ }^{1}$ \\ ${ }^{1}$ Department of Economics, University of National and World Economy, Sofia, Bulgaria \\ Correspondence: Emilia Georgieva, Department of Economics, University of National and World Economy, \\ Studentski Grad, Sofia 1700, Bulgaria. Tel: 359-889-700-483. E-mail:eguerguieva@abv.bg
}

Received: September 5, 2012

Accepted: October 9, 2012 Online Published: November 26, 2012

doi:10.5539/res.v4n5p191

URL: http://dx.doi.org/10.5539/res.v4n5p191

\begin{abstract}
The acronym BELL stands for the 4 EU member countries from Central and Eastern Europe (Bulgaria, Estonia, Latvia and Lithuania) which are well known for their fiscal stability and low indebtedness. Being a representative of one of them (Bulgaria) the author of this article aims to follow the dynamics of their economic development after their accession to the EU. The special points of reference used are the compulsory convergence criteria each country wishing to join the Eurozone has to meet. Particular attention has been paid to the role of the exchange rate regime and the impact of the world economic crisis on the cycle model and the "corridor" marking the fluctuations of each of the interpreted macroeconomic indicators. The BELL's economic development has been opposed to that of the PIIGS countries, albeit only in terms of budget deficit (-) or surplus $(+)$ and consolidated general debt as a percentage of GDP. The author has examined the role the European funds and programmes play for the economies of the BELL countries, some major benefits of their EU membership for their citizens and businesses, as well as the specific characteristics of the social activity aimed to overcome the effects of the crisis.

A variety of research methods have been used in the process, such as the scientific abstraction method (analysis, synthesis, induction and deduction), historic and systemic and logical methods, empirical and comparative analysis.
\end{abstract}

Keywords: EU, BELL, PIIGS, economy, currency board, world economic crisis

\section{Introduction}

In May 2012 yet another acronym - "BELL" was added to the list of acronyms related to European issues. It was officially used by the well-known Polish economist Prof. Leszek Balcerowicz at a lecture at the London School of Economics - "The Eurozone's awkward threesome: fiscal stance, macroeconomic stability and growth" (Note 1). He uses the acronym to establish a relation among the fiscally stable EU countries from Central and Eastern Europe (CEE) among which are Bulgaria, Estonia, Latvia and Lithuania. The first letter of the countries' names produce the acronym, which will be used more and more often not only for the above stated reason, but it will be opposed to (just like Prof. Balcerowicz does) the other popular one - PIIGS (Portugal, Ireland, Italy, Greece, Spain). Unlike BELL, the acronym PIIGS is used to illustrate the opposite trend - a group of EU and Eurozone member states which show fiscal instability.

Bearing in mind the fact that currently not many countries in the European Union can be given as an example of fiscal stability and low indebtedness (especially countries in Central and Eastern Europe) and considering the importance of promoting this positive experience both within and outside the European Union, we aim at looking into the positive indicators of fiscal stability the four countries have in the context of their common economic development after joining the EU. It is quite understandable that the focus will be on Bulgaria since our personal observations of its economic development are thorough, direct and reliable.

\section{Some Preliminary Notes}

Prior to expressing our understanding about the reasons why it has become possible for Bulgaria, Estonia, Latvia and Lithuania to become members of the same group, we would like to point out that they bear a number of other similarities. For example, all four countries are former socialist countries and three of them (Estonia, Latvia and Lithuania) belonged to the former Soviet Union (Note 2), while Bulgaria was closely connected with 
it economically and politically (Note 3). From 1949 until 1991 these countries were members of the Council for Mutual Economic Assistance (CMEA), and from 1955 until 1991 they were members of the Warsaw Treaty Organisation (Warsaw Pact).

After leaving the Soviet Union and the recognition of their independence, Estonia, Latvia and Lithuania (Note 4) aimed at membership of a number of recognized European, Euro-Atlantic and world organizations, thus facilitating considerably their accession to the European Union. After the start of the reforms Bulgaria also aimed at joining these organizations. The four countries first became members of the biggest political organization on the European continent - the Council of Europe (CE) (Note 5). They have been members of the Organisation for Security and Co-operation in Europe (OSCE) since 01.01.1995. All four countries joined the biggest military Euro-Atlantic organization - North Atlantic Treaty Organisation (NATO) on 29.03.2004 and one after the other the World Trade Organisation (WTO) (Note 6). They underwent a combination of political and economic transformations which facilitated their inclusion in the new environment in United Europe.

Despite being members of the above mentioned economic, political, military and security organizations, Bulgaria, Estonia, Latvia and Lithuania actively participate in the co-operation and integration processes in their respective regions - The Black Sea region (for Bulgaria) and the Baltic one (for Estonia, Latvia and Lithuania). Bulgaria, in particular, is a co-founder and since 25.06.1992 has been a member of the Organization of the Black Sea Co-operation (BSEC). Since 01.06.1996 it has been a member of the Central European Initiative (CEI) and between 01.01.1999 and 31.12.2006 - a member of the Central European Free-Trade Agreement (CEFTA). The Baltic countries participate in two regional organizations - the Confederation among Sweden, Finland, Estonia and Lithuania and the Baltic Assembly (Estonia, Latvia and Lithuania) (Note 7).

\section{BELL's Progress towards EU Accession}

It is interesting to point out that the BELL countries put the beginning of their EU accession process while all four of them were still part of CMEA (Estonia, Latvia and Lithuania were still Soviet republics). The start was marked by signing the so-called Luxembourg Declaration on 25.06.1988 between CMEA and the European Economic Community (EEC) (Note 8), thus officially recognizing the two organizations and establishing formal relations. Then followed the signing of the so-called "First generation" Agreements which regulate the economic relations between the CMEA countries (including the ones under consideration) and the EEC based on the principle of the most favoured nation. Shortly after that the "Second generation" Agreements, known as "European Association Agreements" (EAA) were signed thus initiating the accession process for all these countries to the EU and outlining the opportunities for gaining full membership.

Since 1997 the four BELL countries followed quite different paths towards their EU membership. Initially they belonged to different groups (waves of enlargement) in terms of pre-accession negotiations held by the European Union. Of the four countries only Estonia was included in the first group, the so-called "Luxembourg group" (with Poland, Slovenia, Hungary and Czech Republic from Central Europe and Cyprus - a Mediterranean state) and the negotiations started on 31.03.1998, while the remaining three countries (Bulgaria, Latvia and Lithuania) were in the "Helsinki group" (along with Romania, Slovakia and Malta), which started the negotiation process two years later - on 15.02.2000.

After the end of the technical negotiations and the evaluation of the individual readiness of each acceding country a decision was made to form two new groups based on a different principle. Until then groups were formed on the " $5+1$ " principle ( 5 from Central Europe and 1 Mediterranean state), which was changed to " $10+$ 2" (10 countries which were better prepared and 2 less prepared for full EU membership). This made it possible for Latvia and Lithuania to join the newly formed "first group" and sign the accession treaty along with Estonia (and seven other states) on 16.04.2003 in Athens, while Bulgaria and Romania remained in the newly formed "second group" to join two years later. The countries in the "second group" signed their accession contract on 25.04.2005 in Luxembourg. The agreement signed by the Baltic States (and all the other countries from the "group of ten" - Poland, Slovakia, Slovenia, Hungary, Czech Republic, Cyprus and Malta) came into effect on 01.05.2004 and Bulgaria and Romania became full EU members on 01.01.2007. From then on each group of countries took along their own path which made it possible for Bulgaria and the three Baltic States (Estonia, Latvia and Lithuania) to form the new BELL group in 2012.

\section{The Economies of Bulgaria, Estonia, Latvia and Lithuania after Their Accession to the EU}

Before we start the analysis of the common and specific economic features of the four BELL countries in the period under consideration, we would like to clear up a few things: 
First, all four countries were to a very high degree hostages of the repressive Soviet model of political and economic development in Central and East European countries. That was why the disintegration of the Soviet Union and the economic and military organizations - CMEA and Warsaw Treaty - brought them much comfort and explains the strong desire, in particular of the Baltic states to dissociate from the USSR (Russia at present) and to change, as it was pointed out in the blog of the Nobel laureate Paul Krugman (though only about Estonia) from Soviet provinces into good European citizens (Note 9).

Second, the transformations in the economies of the four countries (and in all other CEE countries) resulted not only from the political changes, but also from the command economy, which had been functioning in these countries for a long time (almost half a century) and their quite understandable desire to find an alternative to their economies. What is common for the economies of these countries after the fall of the Iron curtain is the large-scale crisis they were hit by (the so called "transition crisis"); the slow economic development, the shocking start of the economic transition, including the chaos and the lack of consistency in carrying out the market changes; the major goal of the structural reforms focusing on building market economy in line with the main characteristics of the established economic structures in the EU member states at that time; the fear and the consequences from the market transformations for the ordinary citizens and so on.

Third, the methods used and the adopted political and economic practices in the four countries have their specific characteristics and uniqueness. The achievements of any one of them were heavily dependent on their state at the start of the transition to market economy, on the selected model of economic policy and the degree of political will to conduct the reforms successfully.

Fourth, both before and after the EU accession the four countries implemented practices and made achievements which provide an answer to a myriad of questions that remain to be considered. For example, all of them have a functioning market economy and show readiness to deal with the competitive pressure exerted by the market forces in the European Union. As a result of the introduction of a Currency Board (Note 10) in three of them (Bulgaria, Estonia and Lithuania) it has become possible to carry out structural reforms and to accelerate the cooperation process with the EU member states. Furthermore, Estonia and Lithuania proved that it is possible to participate in the European Exchange Rate mechanism (ERM II) (Note 11) while under a Currency Board. Prior to its accession to the Eurozone on 01.01.2011 Estonia, just like the other two Baltic States (Lithuania under a Currency Board and Latvia under a quasi-Currency Board (Note 12)) at present, had been part of the ERM II, while Bulgaria is looking forward to better times to join. This makes Latvia and Lithuania's claims for joining the Eurozone in 2014 quite plausible. This will be Lithuania's second attempt (note 13) to join it.

Fifth, all four countries are members of the European Economic Area (EEA) (Note 14), with Estonia being the best performer, and the Organization for Economic Co-operation and Development (OECD) - an influential economic organization.

The current analysis of the economies of the BELL countries jointly and individually will be based on a selected totality of indicators. This selection has been determined by their EU accession agreements which clearly set forth the requirement to membership in the Economic and Monetary Union (EMU). As they progress to achieve these goals, these countries should meet certain criteria, other than the ones needed for EU membership (known as "the Copenhagen criteria"). These are the conventional criteria from Maastricht (the Maastricht criteria): the budget deficit, the national debt, the inflation rate, the long-term interest rate and the stability of the exchange rate (Note 15). Their impact is further strengthened by the existing criteria for closer cooperation of the respective country with its key foreign partner(s); by institutional, political, legal and other criteria which are of increasing importance for determining the optimum exchange rate mechanism.

Since this analysis focuses on the macroeconomic aspect of the economy and has to meet certain limits in terms of content, we have selected only the most important indices among which are: GDP in current prices, GDP per capita and real GDP growth; unemployment and inflation rates; budget deficit and national debt as a percentage of GDP. These indices will be discussed for two separate sub-periods - before and after the start of the world financial and economic crisis. For the Baltic States these two periods can quite easily be outlined since the crisis divided the period of their EU membership in two equal parts, while in Bulgaria it coincided with its EU accession. We intend to pay particular attention to the comparison between the parameters of two of the key macroeconomic indicators - budget deficit and national debt as a percentage of GDP in the BELL countries and the PIIGS.

Table 1 shows the total production volume jointly for all four countries and for each one individually. It is quite evident that their combined gross domestic product (Note 16) cannot amount to even $1 \%$ of that of EU-27, which ensues from the fact that the four countries (especially the Baltic ones) are small both in territory and in terms of 
population (Note 17) - they occupy just $6.67 \%$ of the entire territory of the EU and their population is only $2.9 \%$ of that of the EU-27 (Note 18). As far as the individual countries from the BELL group are concerned Bulgaria has the biggest nominal GDP, while Estonia has the lowest. Almost for the entire $2007-2011$ period this difference was between 2 and 2.5 times to the advantage of Bulgaria. What is more, only Malta as an EU member has a lower GDP than Estonia, which if expressed in numbers means that at the end of the period Bulgaria ranked $21^{\text {st }}$ in the EU. Lithuania came $23^{\text {rd }}$, Latvia was $24^{\text {th }}$ and Estonia was last in the $26^{\text {th }}$ place (with only one exception - in 2007 Cyprus took the last but one place).

Since the nominal GDP reflects the changes in the current price level, not only the current production, it is usually given as reference and supported by data about two other related indicators - GDP per capita and the real GDP growth.

First, according to GDP per capita in terms of purchasing power standard (Table 2) all four countries from the BELL group are below the average EU level $(E U-27=100)$. Estonia registered the highest GDP for the period under consideration. It should be pointed out that in the year prior to their EU accession (2003) the values of that indicator in the three Baltic countries were below 60 (55 for Estonia, 49 for Lithuania and 43 for Latvia), whereas at the end of the period - they are above or almost 60 (67 for Estonia, 62 for Lithuania and 58 for Latvia). Before the crisis Estonia reported the highest values for the period of its membership (70), then started the drop in GDP which reached 64 (in 2009 and 2010) and its current value is 67 (2011).

Similar developments can be observed in Latvia and Lithuania - an increase until 2007 - 2008 and then a drop of $4-6$ percentage points in 2009 and 2010, and then again an increase at the end of the period (7 percentage points for Latvia, reaching 58, and an increase by 5 percentage points for Lithuania - up to 62). Only Bulgaria (from the end of the $90 \mathrm{~s}$ of the last century) reported a tendency toward an uninterrupted increase and levelling out (in the 2008 - 2010 period), but sadly this was not of great help since after the accession ( 2007 onwards) Bulgaria has constantly taken the last place under this indicator in EU-27, after (though by little) Romania.

Even its highly ambitious goal to catch up with the current level in the Baltic States by 2020 (in 2011 it was 62.3 on average) will not get it any closer to them (despite the similar values they had in the mid-90s of the XX century: 32 for Bulgaria, 36 for Estonia, 35 for Lithuania and 31 for Latvia) and this will hardly allow Bulgaria to get rid of the 'poorest state in the EU' qualification and the country 'with the highest level of inequality in Europe'.

Table 1. GDP (in current prices) of the BELL countries for 2004 - 2011 (mln. Euro)

\begin{tabular}{lcccccccc}
\hline Country & 2004 & 2005 & 2006 & 2007 & 2008 & 2009 & 2010 & 2011 \\
\hline Bulgaria & 20387,9 & 23255,8 & 26476,7 & 30772,4 & 35430,5 & 34932,8 & 36052,4 & 38483,2 \\
Estonia & 9685,3 & 11181,7 & 13390,8 & 16069,4 & 16304,2 & 13839,6 & 14305,3 & 15973,0 \\
Latvia & 11154,6 & 12927,8 & 15981,9 & 21026,5 & 22889,8 & 18521,3 & 17974,8 & 20049,6 \\
Lithuania & 18244,8 & 20969,1 & 24104,2 & 28738,8 & 32461,7 & 26620,1 & 27535,4 & 30705,4 \\
BELL GDP & 59472,6 & 68334,4 & 79953,6 & 96607,1 & 107086,2 & 93913,8 & 95867,9 & 105211,2 \\
EU-27 GDP & 1060981 & 1106029 & 1169513 & 1239770 & 1246709 & 1174250 & 1226049 & 12629522, \\
BELL GDP & 9,9 & 7,4 & 9,3 & 5,2 & 7,7 & 9,8 & 5,1 & 8 \\
as \% of & 0,56 & 0,62 & 0,68 & 0,78 & 0,86 & 0,80 & 0,78 & 0,83 \\
EU-27 GDP & & & & & & & & \\
\hline
\end{tabular}

Source: Eurostat

Table 2. GDP per capita of the BELL countries in terms of purchasing power standard (PPS) for $2004-2011$ $(\mathrm{EU}-27=100)$

\begin{tabular}{lllllllll}
\hline Country & 2004 & 2005 & 2006 & 2007 & 2008 & 2009 & 2010 & 2011 \\
\hline Bulgaria & 35 & 37 & 38 & 40 & 44 & 44 & 44 & 45 \\
Estonia & 57 & 62 & 66 & 70 & 69 & 64 & 64 & 67 \\
Latvia & 46 & 48 & 51 & 56 & 56 & 51 & 51 & 58 \\
Lithuania & 51 & 53 & 56 & 59 & 61 & 55 & 57 & 62 \\
\hline
\end{tabular}

Source: Eurostat 
The next criterion of actual convergence is the real GDP growth. It is mainly related to upward dynamics of the final economic result and is measured by the GDP growth rate. According to data provided by Eurostat and the EU latest forecasts (autumn for 2011, median and spring for 2012) (Note 19) it illustrates quite effectively the common and different aspects between the economic performance before, during and after the crisis and the direction of the macroeconomic dynamics for each of the 4 studied countries. Its parameters are closely related to the exchange rate regime there and to the duration of the implemented government regime of fixed exchange rate in three of them.

The data in Table 3 and the conclusions based on the parameters of this indicator in the other EU countries show that before the crisis (for Estonia, Latvia and Lithuania it coincided with the first half of their EU membership, while for Bulgaria - with the years of active preparation for EU membership) all four countries achieved rates of economic growth which considerably exceeded the growth rates in EU-27 (of the Eurozone and even the world economy). The main reason for that being the flow of foreign capital (for Bulgaria it was one of the highest - 30\% of GDP for 2007), the expectations for quick convergence, the conducted strict fiscal policy, the low labour costs etc.

Table 3. Real GDP growth rate in the BELL countries for the $2004-2011$ period (\%)

\begin{tabular}{lllllllll}
\hline Country & 2004 & 2005 & 2006 & 2007 & 2008 & 2009 & 2010 & 2011 \\
Bulgaria & 6,7 & 6,4 & 6,5 & 6,4 & 6,2 & $-5,5$ & 0,4 & 1,7 \\
Estonia & 6,3 & 8,9 & 10,1 & 7,5 & $-3,7$ & $-14,3$ & 2,3 & 7,6 \\
Latvia & 8,9 & 10,1 & 11,2 & 9,6 & $-3,3$ & $-17,7$ & $-0,3$ & 5,5 \\
Lithuania & 7,4 & 7,8 & 7,8 & 9,8 & 2,9 & $-14,8$ & 1,4 & 5,9 \\
EU-27 & 2,5 & 2,0 & 3,3 & 3,2 & 0,3 & $-4,3$ & 2,0 & 1,5 \\
\hline
\end{tabular}

Source: Eurostat

However, we cannot ignore the fact that the world financial and economic crisis seriously hit the countries under a Currency Board. Furthermore, the suddent record high slump in the Baltic States is due to their size (all three countries are rather small) and the limited domestic demand (consumer, governmental and investment) related to that fact. We should also point out the relations of these countries with their foreign partners, some of which are more seriously affected by the crisis than others (including some neighbouring less or more developed economies - for example, Greece as a neighbour of Bulgaria and the Scandinavian countries - neighbours of the three Baltic States).

Further details focusing on the economic activity in the BELL countries illustrate a similar trend. For example, in the first half of the period after accession the three Baltic States $(2004-2007)$ witnessed an upward trend in their GDP, while in 2008 and in 2009 in particular, the positive trend encountered a L-shaped interruption (there was only one lowest point in 2009) and an upward trend in the following years (2010 and 2011). The real GDP growth rates in Estonia varied from $+10.1 \%$ in 2006 to $-14.3 \%$ in 2009 ; in Latvia - from $+11.2 \%$ (in 2006) to $-17.7 \%$ (in 2009); in Lithuania - from $+9.8 \%$ (in 2007) to $-14.8 \%$ (in 2009).

In comparison to the Baltic States Bulgaria reported much better results in terms of this indicator - after its accession (since 2007 and a few years before that) Bulgaria reported negative economic growth only once (5.5\% in 2009 - the most difficult year during the crisis), which differed significantly from that of the BELL countries with the highest negative growth - Latvia (-17.7\% in 2009) and that with the lowest - Estonia (-14.3\% for the same year). According to research carried out by Stati Statev, the transmission mechanisms in the Bulgarian economy are directed from the real economy toward the financial sector, which implies that in order to stimulate growth certain activities in the real economy should be developed (through foreign investments or through public procurement) (Note 21).

The assumption that the cycle in the BELL countries might bear some peculiarities is substantiated by the unemployment coefficient registered in the four countries. This indicator is identical to the economic growth: the values of this indicator are U-shaped, dually symmetrical and are likely to gradually decrease this year and in 2013 (according to the forecasts of the European Commission). Record high results were registered in 2010 (16.9\% for Estonia, $18.7 \%$ for Latvia and $17.8 \%$ for Lithuania) which improved considerably in 2011 (by 4.4 percentage points in Estonia, 2.5 percentage points in Latvia and 2.4 percentage points in Lithuania). The 
expectations for 2012 and 2013 are for the values of this indicator to reach levels of $11.6 \%$ and $10.5 \%$ in Estonia; $14.8 \%$ and $13.2 \%$ in Latvia and $13.8 \%$ and $12.7 \%$ in Lithuania (Note 22 ).

Table 4. Coefficient of unemployment in the BELL countries for the 2004-2011 period (\%)

\begin{tabular}{lllllllll}
\hline Country & 2004 & 2005 & 2006 & 2007 & 2008 & 2009 & 2010 & 2011 \\
\hline Bulgaria & 12,1 & 10,1 & 9,0 & 6,9 & 5,6 & 6,8 & 10,2 & 11,2 \\
Estonia & 9,7 & 7,9 & 5,9 & 4,7 & 5,5 & 13,8 & 16,9 & 12,5 \\
Latvia & 10,4 & 8,9 & 6,8 & 6,0 & 7,5 & 17,1 & 18,7 & 16,2 \\
Lithuania & 11,4 & 8,3 & 5,6 & 4,3 & 5,8 & 13,7 & 17,8 & 15,4 \\
EU-27 & 9,2 & 9,0 & 8,3 & 7,2 & 7,1 & 9,0 & 9,7 & 9,7 \\
\hline
\end{tabular}

Source: Eurostat

Although the trend observed in Bulgaria is negative (with negligible but constant increase in the parameters of this indicator, including the first six months of 2012, when it reached and remained above $12 \%$ ), the unemployment rate remains lower than that in Lithuania and in Latvia, in particular. Once again this explicitly shows that growth cannot be a substitute for employment, and it does not automatically result in lower unemployment, social tension and the number of emigrants, which has reached a considerable number in the Baltic States. For example, only in Latvia nearly 200000 people, which is $10 \%$ of the population, have left the country over the past decade.

Inflation rate is another equally important indicator. It should be analyzed in the context of the Maastricht criteria - for the countries applying for Eurozone membership, on the one hand and as a target set by the ECB in reference to its major goal - to maintain price stability in the Eurozone, on the other. This means that for Bulgaria, Latvia and Lithuania the interest rate should be analyzed following the first method of approach, while for Estonia as a member of the Eurozone - following the second. Since Bulgaria and the two Baltic States mentioned above are quite likely to join the Eurozone, we will observe the dynamics of this indicator following both approaches.

Calculated under the most popular method - through a change in the harmonized index of consumer prices (HICPs) (Note 23) - the inflation in the BELL countries as full EU members can be described as mainly moderate and only during certain years (for all 4 countries) as speeding up (in 2007 in Latvia and in 2008 in all four of them) (Note 24). As far as the so-called inflationary differential (Note 25) between the four BELL countries and their main trade and economic partner - the Eurozone - is concerned, for the individual years (for instance 2008) it is quite high and in Latvia in particular, it reached a two-digit figure (12.0\%). At the end of the period (2011) Bulgaria reported the lowest inflationary differential (0.7\%), while Estonia had the highest (2.4\%), followed by Latvia (1.5\%) and Lithuania (1.4\%). Research shows that a considerable part of the inflationary differential between Bulgaria immediately before its EU accession and the Eurozone (01.01.2007) is due to the Balassa-Samuelson effect with a downward trend in its impact on inflation and the real effective exchange rate (Note 26).

Table 5. Average annual inflation rate in the BELL countries for $2004-2011$ (\%)

\begin{tabular}{lllllllll}
\hline Country & 2004 & 2005 & 2006 & 2007 & 2008 & 2009 & 2010 & 2011 \\
\hline Bulgaria & 6,1 & 6,0 & 7,4 & 7,6 & 12,0 & 2,5 & 3,0 & 3,4 \\
Estonia & 3,0 & 4,1 & 4,4 & 6,7 & 10,6 & 0,2 & 2,7 & 5,1 \\
Latvia & 6,2 & 6,9 & 6,6 & 10,1 & 15,3 & 3,3 & $-1,2$ & 4,2 \\
Lithuania & 1,2 & 2,7 & 3,8 & 5,8 & 11,1 & 4,2 & 1,2 & 4,1 \\
Eurozone (17) & 2,2 & 2,2 & 2,2 & 2,1 & 3,3 & 0,3 & 1,6 & 2,7 \\
EU-27 & 2,0 & 2,2 & 2,2 & 2,3 & 3,7 & 1,0 & 2,1 & 3,1 \\
\hline
\end{tabular}

Source: Eurostat 
Further to the above data about inflation we should also add that Estonia shows a logical tendency towards a certain increase in the prices in the first year of its Eurozone membership (as it happened with Slovenia, Cyprus and Malta) and then (as it is pointed out in the spring forecast issued by the European Commission) it is expected that inflation will stabilize ( $3.9 \%$ in 2012 and $3.4 \%$ in 2013). It is expected that the other three BELL countries will continue to register low parameters of this indicator for several uneventful postcrisis years so that at least Latvia and Lithuania will manage to convince the European institutions that they deserve to join the Eurozone in the near future.

Now that we have outlined certain facts and drawn conclusions about the recurrent fluctuations observed in a group of macroeconomic indicators in the BELL countries, we quite logically reach the point in their economies that puts them together in one group. This is the general budget deficit $(-)$ and surplus $(+)$ and the general consolidated government debt as a percentage of GDP. It is in this area that the four countries register results which allow them to be described as "fiscally disciplined countries".

In theory, when under a Currency Board the size of the budget deficit should be limited or nullified in the short term period (Note 27) and on the basis of the data provided in Table 6 we can conclude that for the 8-year period between 2004 and 2011 Estonia had a budget surplus for 6 years and a budget deficit for 2; Latvia and Lithuania have not had Estonia's success because they have not had such budget surplus for the 8-year period of their EU membership. During the 5-year membership Bulgaria registered a budget surplus for 2 years (2007 and 2008) and three years of budget deficit (between 2009 and 2011).

Table 6. General budget deficit(-) or surplus (+) as a percentage of GDP in the BELL countries for $2004-2011$

\begin{tabular}{lllllllll}
\hline Country & 2004 & 2005 & 2006 & 2007 & 2008 & 2009 & 2010 & 2011 \\
\hline Bulgaria & 1,9 & 1,0 & 1,9 & 1,2 & 1,7 & $-4,3$ & $-3,1$ & $-2,1$ \\
Estonia & 1,6 & 1,6 & 2,5 & 2,4 & $-2,9$ & $-2,0$ & 0,2 & 1,0 \\
Latvia & $-1,0$ & $-0,4$ & $-0,5$ & $-0,4$ & $-4,2$ & $-9,7$ & $-8,3$ & $-3,5$ \\
Lithuania & $-1,5$ & $-0,5$ & $-0,4$ & $-1,0$ & $-3,3$ & $-9,5$ & $-7,0$ & $-5,5$ \\
Eurozone(17) & $-2,9$ & $-2,5$ & $-1,3$ & $-0,7$ & $-2,1$ & $-6,4$ & $-6,2$ & $-4,1$ \\
EU-27 & $-2,9$ & $-2,4$ & $-1,5$ & $-0,9$ & $-2,4$ & $-6,9$ & $-6,6$ & $-4,5$ \\
\hline
\end{tabular}

Source: Eurostat

Despite the restrictions which ensue from the specific nature of their exchange rate regime, the four BELL countries signed the Treaty on Stability, Coordination and Governance in the Economic and Monetary Union on 02.03.2012 in Brussels (the treaty should come into force on 01.01.2013) (Note 28). This suggests that they consolidate on "the introduction of special rules, including "the balanced budget" one and agree to an automatic mechanism for corrective actions" (Note 29), confirm their readiness to ensure that "the budgetary position of the general government of a Contracting party shall be balanced or in surplus" (article 3, point 1a); agree that the rule under article 3, point 1a "shall be deemed to be respected if the annual structural balance of the general government is at its country-specific medium-term objective, as defined in the revised Stability and Growth Pact". (Note 30)

Currently, of the four BELL countries Estonia and Bulgaria are not subject to an excessive deficit procedure. Data provided by the Bulgarian Ministry of Finance show that at the end of the first half of 2012 revenues slightly exceeded expenditure in the consolidated budget, amounting to BGN $61.9 \mathrm{mln}(0.1 \%$ of the forecast GDP). Fitch rating agency states that Bulgaria will succeed in reaching the planned budget deficit for 2012 mostly as a result of the successful expenditure control (in 2009 expenditure amounted to 40.7\% of GDP, in $2010-37.4 \%$, and in $2011-35.2 \%$ (compared to $49.1 \%$ for the EU-27 and $49.3 \%$ for the Eurozone in 2011)

Closely related to the budget deficit in general, and in this specific case for the BELL countries, is the next macroeconomic indicator - consolidated general government debt as a percentage of GDP. Its parameters explicitly illustrate the degree of stability of the public finance and the political will to strengthen the financial stability. They are dependent on the fact that the debt can be considered not only as a budget deficit accumulated over time, but also as a result from the policy led in terms of providing the financial resources needed for its servicing (principal and interest payments). The EU member states have to meet the requirement for $60 \%$ limit for debt/GDP ratio, set out in the Maastricht Treaty (exactly 20 years ago). 
As far as the BELL countries are concerned, all four countries have earned their right to be given as a positive example. For all four countries this indicator is not even close to the Maastricht requirement of $60 \%$ of GDP, even in those cases when it is higher (this holds true for Latvia and Lithuania).

Table 7. Consolidated General Government Debt as a Percentage of GDP of the BELL countries for 2004 - 2011

\begin{tabular}{lllllllll}
\hline Country & 2004 & 2005 & 2006 & 2007 & 2008 & 2009 & 2010 & 2011 \\
\hline Bulgaria & 37,0 & 27,5 & 21,6 & 17,2 & 13,7 & 14,6 & 16,3 & 16,3 \\
Estonia & 5,0 & 4,6 & 4,4 & 3,7 & 4,5 & 7,2 & 6,7 & 6,0 \\
Latvia & 15,0 & 12,5 & 10,7 & 9,0 & 19,8 & 36,7 & 44,7 & 42,6 \\
Lithuania & 19,3 & 18,3 & 17,9 & 16,8 & 15,5 & 29,4 & 38,0 & 38,5 \\
Eurozone (17) & 69,6 & 70,2 & 68,6 & 66,3 & 70,1 & 79,9 & 85,3 & 87,2 \\
EU-27 & 62,3 & 62,9 & 61,6 & 59,0 & 62,5 & 74,8 & 80,0 & 82,5 \\
\hline
\end{tabular}

Source: Eurostat

Undoubtedly Estonia is the absolute leader in the group since it joined the EU with merely $5.6 \%$ government debt of the GDP (for 2003), managed to keep it below 10\% even during the crisis and according to the spring forecast issued by the European Commission it is expected that for the first time after joining the EU Estonia will have a debt of $10.4 \%$ in 2012 and $11.7 \%$ in 2013. Bulgaria comes immediately after Estonia with the most impressive positive changes (if we also consider the years before its EU membership) - since 2007 the parameters of this indicator have never exceeded the ones reported at the start of its EU membership on 01.01.2007 (21.6\% for 2006). Thus, Estonia and Bulgaria are the two BELL countries and EU member states, which along with Luxembourg (the values of this indicator from 2003 until 2011 are as follows: $6.1 \%$; 6.3\%; $6.1 \% ; 6.7 \% ; 6.7 \% ; 13.7 \% ; 14.8 \% ; 19.1 \%$ and $18.2 \%$ ) are in the lead. Big EU member states are behind them, including members of the Eurozone, which turned from perfect examples of frugality into an example of high indebtedness (one example is France whose debt in 2011 was $85.8 \%$ of GDP, that of Great Britain - 85.7\% and Germany $-81.2 \%$ etc.)

And finally we are to compare the achievements of the BELL countries in the field of public finance to those of the PIIGS countries (the Eurozone and EC-27 respectively). The general conclusion that can be drawn on the basis of the data presented in Table 8 and Table 9 and compared to the data in Tables 6 and 7 is that the budget deficit as a percentage of GDP of the BELL countries differs significantly from that of the PIIGS and from the average for the EU and the Eurozone. This applies especially to Estonia and Bulgaria, which managed to maintain much stricter fiscal discipline (in 2010 it was ten times stricter than Ireland's) than the PIIGS countries in the most difficult years (for Bulgaria that was 2009 and 2008 for Estonia), reporting unprecedented double digit figures of the budget deficit $-31.3 \%$ in Ireland in 2010, 15.8\% in Greece in 2009. 11.2\% in Spain in 2009, $10.1 \%$ in Portugal in 2009 etc.

Table 8. General Budget Deficit of the PIIGS Countries as a Percentage of GDP for 2004 - 2011

\begin{tabular}{lllllllll}
\hline Country & 2004 & 2005 & 2006 & 2007 & 2008 & 2009 & 2010 & 2011 \\
\hline Portugal & $-3,4$ & $-5,9$ & $-4,1$ & $-3,1$ & $-3,6$ & $-10,1$ & $-9,8$ & $-4,2$ \\
Ireland & 1,4 & 1,7 & 2,9 & 0,1 & $-7,3$ & $-14,2$ & $-31,3$ & $-13,1$ \\
Italy & $-3,5$ & $-4,4$ & $-3,4$ & $-1,6$ & $-2,7$ & $-5,4$ & $-4,6$ & $-3,9$ \\
Greece & $-7,5$ & $-5,2$ & $-5,7$ & $-6,5$ & $-9,8$ & $-15,8$ & $-10,6$ & $-9,1$ \\
Spain & $-0,1$ & 1,3 & 2,4 & 1,9 & $-4,5$ & $-11,2$ & $-9,3$ & $-8,5$ \\
Eurozone (17) & $-2,9$ & $-2,5$ & $-1,3$ & $-0,7$ & $-2,1$ & $-6,4$ & $-6,2$ & $-4,1$ \\
EU-27 & $-2,9$ & $-2,4$ & $-1,5$ & $-0,9$ & $-2,4$ & $-6,9$ & $-6,6$ & $-4,5$ \\
\hline
\end{tabular}

Source: Eurostat 
Table 9. Consolidated General Government Debt of the PIIGS countries as a Percentage of GDP for 2004 - 2011

\begin{tabular}{lllllllll}
\hline Country & 2004 & 2005 & 2006 & 2007 & 2008 & 2009 & 2010 & 2011 \\
\hline Portugal & 61,9 & 67,7 & 69,3 & 68,3 & 71,6 & 83,1 & 93,3 & 107,8 \\
Ireland & 29,4 & 27,2 & 24,5 & 24,8 & 44,2 & 65,1 & 92,5 & 108,2 \\
Italy & 103,4 & 105,4 & 106,1 & 103,1 & 105,7 & 116,0 & 118,6 & 120,1 \\
Greece & 98,6 & 100,0 & 106,1 & 107,4 & 113,0 & 129,4 & 145,0 & 165,3 \\
Spain & 46,3 & 43,2 & 39,7 & 36,3 & 40,2 & 53,9 & 61,2 & 68,5 \\
Eurozone (17) & 69,6 & 70,2 & 68,6 & 66,3 & 70,1 & 79,9 & 85,3 & 87,2 \\
EU-27 & 62,3 & 62,9 & 61,6 & 59,0 & 62,5 & 74,8 & 80,0 & 82,5 \\
\hline
\end{tabular}

Source: Eurostat

It is of particular importance to underline the fact that the Maastricht requirement of 3\% budget deficit as a percentage of GDP is something the PIIGS can only hope for, rather than a standard of behaviour. With the exception of Ireland where the reported excessive deficits are due to reasons that differ radically from the ones in the other 4 countries in the group, it was difficult for all of them to meet the criteria prior to their Eurozone membership and they find it hard to filfill them now that they are already members.

The situation observed in terms of the consolidated government debt as a percentage of GDP is identical to what we observed in terms of the budget deficit in the BELL and PIIGS countries. Certain similarities in the macroeconomic and political environment in the countries belonging to these two groups have led to results which put them in a completely different position. On the one hand, meticulously observing crucial requirements in the area of fiscal policy under the Currency Board (and/or long-term implementation of fixed exchange rate) along with the implementation of a more flexible budget and debt policy was the reason why the BELL countries managed to keep low debt rates after their EU accession (especially Estonia and Bulgaria). The continuous breach of the financial discipline, including the increase in government spending and the slump in revenue as a result of the recession led to serious debt problems for the PIIGS countries and they epitomise the debt crisis in the periphery of the Eurozone.

\section{The Role of the European Funds and Programmes in the Economic Development of the BELL Countries}

During their EU accession process and later as full EU members the BELL countries (being part of the larger group of the CEEC) were granted different types and amounts of financial aid by the EU. As applicant counrtries Bulgaria, Estonia, Latvia and Lithania were the beneficiaries of the pre-accession PHARE, ISPA and SAPARD financial instruments aimed at the CEEC as well as of some other programmes specially opened for them.

As of the start of their EU membership the CEEC countries, the BELL countries included, gained not only a number of new rights but got access to significant financial help within the so called Structural Funds and the Cohesion Fund (CF). For the 2000 - 2006 financial framework there were four structural funds, while for the 2007-2013 there are two - European Regional Development Fund (ERDF) and the European Social Fund (ESF). The Cohesion Fund (CF) has been functioning since 1993.

Unlike the structural funds which are regional, the $\mathrm{CF}$ is aimed at the EU member states with slow economic development. Initially these were Greece, Ireland, Spain and Portugal and currently the three already mentioned (with the exception of Ireland) were joined by the twelve new member states, accepted during the 2004-2007 period.

As key tools of the so called EU policy to reduce disparities, the structural and the Cohesion Fund aim to finance a wide range of priorities and activities. ERDF was set up in 1975 to provide funds for the three major objectives of the 2007-2013 financial framework - "Convergence", "Regional Competitiveness and Employment" and "European Territorial Cooperation". The ESF, set up in 1960, funds the first two major objectives of the 2007-2013 financial framework and two other crucial priorities in this field. The CF provides funds for big transeuropean networks and environmental projects. The pre-accession ISPA programme focuses to a very great extent on the priorities and activities which are in the focus of this fund.

Channelling a significant part of its budget toward strengthening and enhancing the competitiveness of the member states' economies (regional ones included), the European Union attentively oversees the efficiency of 
the absorbtion of the allocated funds. According to data, issued by the EC, the financial implementation of the structural funds (as a ratio between paid-out and undertaken budget liabilities) for 2000-2006 (as to 2010) for three of the BELL countries - Estonia, Latvia and Lithuania (Bulgaria was not a EU member at that time) is as follows: Estonia - 94.95\%, Latvia and Lithuania - 95.00\% each.

For the same 2000-2006 programme period (as to 2010 again) the CF (ex-ISPA included) financial implementation (the adopted amounts) as a ratio between the paid-out amounts and the undertaken budget liabilities for the three Baltic republics has the following values: Estonia $-86.70 \%$, Latvia $-81.00 \%$, Lithuania $83.80 \%$ and Bulgaria $-70.10 \%$. The best performing country, Ireland, reports $92.80 \%$, while the countries which this fund was set up for report the following results: Greece- $83.80 \%$, Spain $-86.40 \%$ and Portugal $-85.50 \%$.

Presented jointly and individually under the three funds the payments as to September 2012 rank the BELL countries as follows: Lithuania comes first $(47.12 \%$ of the total payments), Estonia comes fourth ( $40.13 \%$ of total payments), Latvia takes the 13th position (34.59\% of total payments) and Bulgaria is 25th (only Czech Republik and Romania are after it) with $17.15 \%$ of total payments. In the lead along with Lithuania rank Portugal (2nd place), Greece (10th) and Spain (11th).

Finally, the state of the interim payments under ESF, ERDF and CF can be discussed on the basis of the total number of operational programmes funded by the three funds and the size of the payments. The total amount of interim payments extended to the BELL countries for 2008 - 2012 amounts to $\square 1114.5$ million under ESF and $\square 6289.9$ under ERDF and CF.

In addition to the above stated, citizens and companies in the EU member states undoubtedly further benefit from the EU membership of their countries. Of particular importance to relatively new member states are the benefits for their citizens in the field of health care (having an European health insurance card with all the rights it grants), education (facilitating access to education, lower tuition fees and credit opportunities, foreign language education etc.); labout and social-insurance rights, consumer rights etc.

Comparable to all these benefits are the ones that the business experiences. Some of the most important are the easier access to financing, bank loans and capital markets; participation in EU programmes and the three specially set up new tools - JASPERS, JEREMIE, JESSICA- for the 2007 - 2013 financial period.

\section{Social Activity Performed in the BELL Countries to Tackle the Crisis}

Having ascertained the fact that the financial and economic crisis has led to a huge economic and human catastrophe, which found expression in a significant drop in GDP and more than 23 million unemployed, the European Union implemented measures to stimulate recovery by using and coordinating both national and European instruments. In 2010 the European Union proposed a strategy for the European social market economy for XXI century, known as "Europe 2020" and in 2012 it agreed on creating "The Growth and Jobs Pact". Both strategies entail social measures aimed to counter the crisis and stimulate better selection of the introduced specific initiatives.

As members of the Eurozone the BELL countries perform this intensified activity both by common (for all four countries) instruments and ones which are typical of three, two or only one of them. Some of the common instruments are: benefits for unemployment, education and facilitating job search. Three of the countries (Bulgaria, Estonia and Lithuania) grant subsidies for start-up business and lower the social security contributions. Bulgaria and Latvia have systems to guarantee minimal incomes and Bulgaria and Estonia facilitate the start of private business and lower corporate tax. Each of the four countries implement highly specific measures meeting the needs of the labour market and a social security policy and support, improving education and qualification, stimulating prevention in health care etc.

\section{Conclusion}

Over the past decade the economies of the BELL countries have undergone transformations and faced some new challenges. First, they changed from command administrative to market economy, then they had to become part of the European and the increasingly globalized world economies, to endure the world financial and economic crisis and finally, try to restore the sustainable and well-balanced growth from before the crisis as the only guarantee for catching up with the developed EU countries.

The anti-crisis policy of the three Baltic states substantiated the Baltic model with its most important charecteristics related to the implementation of fast and radical reforms, rejection of the currency and introducing the so called internal devaluation (in the form of lowering salaries and increasing productivity), drastic public spending cuts. 
Bulgaria made certain efforts to restore its macroeconomic stability affected by the crisis. Currently the country is known for the lowest rates of the corporation and income tax in the EU of $10 \%$ (the average in the EU is $23.5 \%$ corporation tax and 38\% income tax in EU and $43 \%$ in the Eurozone), lack of loans granted by the international financial institutions etc. The money granted under the eurofunds is expected to have a long-term positive impact on the GDP growth, the country's public debt, foreign trade and the current account deficit.

\section{References}

Balcerowicz, L. (2012). Warsaw School of Economics. The Eurozone's awkward threesome: fiscal stance, macroeconomic stability and growth. London School of Economics. 8th May.

Consolidated version of the Treaty on European Union and the Treaty on the Functioning of the European Union. Official journal of the European Union. 30.03.2010г. Retrieved from http://eur-lex.europa.eu/LexUriServ/LexUriServ.do?uri=OJ:C:2010:083:FULL:EN:PDF

Marinov, V. (1993). Towards New Economic Architecture in Europe. Sofia: "Stopanstvo" Publishing House.

Savov, S. et al. (1998). Economics (2nd ed.). Sofia: "Trakia-M" Publishing House.

Simeonov, K. (2007). The Road to the Eurozone - to sail or not to sail. Sofia: Minerva.

Statev, S. (2012, June 26). Speech made at a conference: "Prerequisites and prospects for sustainable economic growth in Bulgaria and Europe". Sofia, UNWE.

Treaty on Stability, Coordination and Governance in the Economic and Monetary Union. Retrieved from http://european-council.europa.eu/media/639253/01_-_tscg.bg.12.pdf

http://ec.europa.eu/economy_finance/publications/european_economy/2011/pdf/ee-2011-6_en.pdf

$\mathrm{http} / /$ ec.europa.eu/economy_finance/publications/european_economy/2012/pdf/ee-2012-1_en.pdf

http://epp.eurostat.ec.europa.eu/tgm/refreshTableAction.do;jsessionid=9ea7d07d30db12b56621 cb21465c969cb2

6aab19f5ab.e34MbxeSaxaSc40LbNiMbxeNahyPe0?tab=table\&plugin=1\&pcode=tec00001\&language=en

http://epp.eurostat.ec.europa.eu/tgm/table.do?tab=table\&init=1\&language=en\&pcode=tec00114\&plugin=1 http://epp.eurostat.ec.europa.eu/tgm/table.do?tab=table\&init=1\&language=en\&pcode=tec00115\&plugin=1 $\mathrm{http} / / /$ epp.eurostat.ec.europa.eu/tgm/table.do?tab=table\&init=1\&language=en\&pcode=tsdec450\&plugin=1 http://epp.eurostat.ec.europa.eu/tgm/table.do?tab=table\&init=1\&language $=$ en\&pcode=tec00118\&plugin $=1$ http://epp.eurostat.ec.europa.eu/tgm/table.do?tab=table\&init=1\&language=en\&pcode=tec $00127 \&$ plugin $=1$ http://epp.eurostat.ec.europa.eu/tgm/table.do?tab=table\&init=1\&language=en\&pcode=tsdde410\&plugin=1 http://krugman.blogs.nytimes.com - from 31.12.2010

http://www.baltasam.org/cooperation

\section{Notes}

Note 1. Prof. Leszek Balcerowicz. Warsaw School of Economics. The Eurozone's awkward threesome: fiscal stance, macroeconomic stability and growth. London School of Economics, May 8th, 2012.

Note 2. At some point Estonia, Latvia and Lithuania were part of the Russian empire (Estonia joined the Russian empire in 1721; Russia's conquest of Latvia started in 1721; Lithuania - in 1795). Later, between the First and Second World Wars they were independent countries. In 1940 they were occupied by the USSR and became part of the Soviet Union (Latvia from 05.08.1940; Estonia and Lithuania from 06.08.1940) until its dissolution in 1991.

Note 3. This became obvious in the 60 s and 70 s of the XX century with the idea for Bulgaria to join the USSR as its $16^{\text {th }}$ republic.

Note 4. Estonia and Latvia on 21.08.1991, while Lithuania on 11.03.1990.

Note 5. Bulgaria since 07.05.1992; Estonia and Lithuania since 14.05.1993; Latvia since 10.02.1995.

Note 6. Bulgaria since 01.12.1996, Estonia since 13.11.1999, Latvia since 10.02.1999, Lithuania since 31.05.2001.

Note 7. Prof. Velko Marinov, Towards A New Economic Architecture in Europe. "Stopanstvo" University Publishing House, S., 1993, p 29; http://www.baltasam.org/ 
Note 8. European Economic Community (EEC) was founded by 6 west European countries - France, Germany, Italy, Belgium, the Netherlands and Luxembourg. The Maastricht Treaty (signed on 07.02.1992 entered into force on 01.11.1993) the EEC was renamed to EC (European Community). The Lisbon Treaty (signed on 13.12.2007 entered into force on 01.12.2009) the European Union is the successor of the European Community.

Note 9. http://krugman.blogs.nytimes.com

Note 10. Estonia and Lithuania were the first to do it (as early as 1992), later (in 1997) Bulgaria joined. A Currency Board was introduced in Estonia and Lithuania with national currency fixed to the German mark (in Estonia) and to the US dollar (in Lithuania). In Bulgaria the national currency (the lev) was fixed to the German mark in the beginning and later to the euro.

Note 11. ERM II is a new currency exchange mechanism in EU which on 01.01.1999 replaced the existing system within the European Monetary System. Its major characteristics are set out in the Amsterdam EU Resolution (16.06.1997). Estonia and Lithuania joined ERM II on 28.06.2004, while Latvia on 02.05.2005.

Note 12. It is specific about Lithuania that the lat is fixed to the euro at 0.702804 but as the country belongs to the ERM II the lat can fluctuate up to $\pm 1 \%$ to the main exchange rate.

Note 13. In March 2006 Lithuania applied for EU membership but the evaluation of its fulfillment of the Maastricht criteria concluded that it had failed to meet the inflation criteria, though only by 0.1 percentage points, so it could not become a member.

Note 14. A specific model of European economic integration including 30 countries: all $27 \mathrm{EU}$ member states and 3 EFTA countries (without Switzerland). The three Baltic republics have been members of EEA since the date their EU accession agreement entered into force (01.05.2004), Bulgaria (and Romania) a bit later than the accession date (01.01.2007) - on 25.07.2007.

Note 15. For further information: Consolidated version of the Treaty on European Union and the Treaty on the Functioning of the EU. EU official journal. 30.03.2010, p. 281-282.

Note 16. All the data used in the article are interpreted in accordance with the adopted Eurostat methodology.

Note 17. BELL countries occupy $288312 \mathrm{~km}^{2}$ in total, while their population amounts to 14566903.

Note 18. EU territory is $4325675 \mathrm{~km}^{2}$, its population is 502486499 .

Note 19. http://ec.europa.eu/economy_financ/publications/european_economy/2012/pdf/ee-2012-1_en.pdf

Note 20. Prof. Stati Statev. Speech made at a conference: "Prerequisites and prospects for sustainable economic growth in Bulgaria and Europe", Sofia, UNWE, 26.06.2012.

Note 21. http://ec.europa.eu/economy_finance/publications/european_economy/2012/pdf/ee-2012-1_en.pdf

Note 22. The ECB uses this indicator to monitor inflation in the Eurozone.

Note 23. According to data provided by Eurostat Bulgaria had the lowest inflation rate among the BELL countries in June $2012-1.6 \%$ (compared to 2.1 in Latvia, 2.6\% in Lithuania and 4.4\% in Estonia).

Note 24. It is calculated as the difference in the percentage change in HICPs in one country and a percentage change of the same index in all countries in the Eurozone (or the entire EC). For further details: Kaloyan Simeonov. The Road to the Eurozone - to sail or not to sail. "Minerva" Publishing House, S., 2007, p.152-153.

Note 25. Kaloyan Simeonov. The Road to the Eurozone - to sail or not to sail. "Minerva" Publishing House, S., 2007, p. 222.

Note 26. See Prof. Rumen Gechev. Fiscal Policy. Chapter 21, Economics. Second edition. "Trakia-M" Publishing House, S., 1998, p.360.

Note 27. Treaty on Stability, Coordination and Governance in the Economic and Monetary Union. http://european-council.europa.eu/media/639253/01_ tscg.bg.12.pdf

Note 28. Ibid. p. 1

Note 29. Ibid. p.11 